\title{
Paraboea khaoyaica (Gesneriaceae), a new species from Thailand
}

\author{
S. Kaitongsuk ${ }^{1,2}$, P. Triboun ${ }^{3}$, S. Suddee ${ }^{2}$, P. Ue-Aree ${ }^{2,4} \&$ S. Sungkaew ${ }^{1,5}$ \\ ${ }^{1}$ Faculty of Forestry, Kasetsart University, Chatuchak, Bangkok 10900, Thailand \\ ${ }^{2}$ Forest Herbarium (BKF), Department of National Parks, \\ Wildlife and Plant Conservation, 61 Phahonyothin Road, \\ Chatuchak, Bangkok 10900, Thailand \\ ${ }^{3}$ National Biobank of Thailand, National Science and Technology \\ Development Agency, 111 Thailand Science Park, Phahonyothin Road, \\ Khlong Nueng, Khlong Luang, Pathum Thani 12120, Thailand \\ ${ }^{4}$ Gardening and Horticulture Department, Xishuangbanna Tropical Botanical Garden, Chinese \\ Academy of Sciences, Menglun, Mengla, 666303, Yunnan, China \\ ${ }^{5}$ Center for Advanced Studies in Tropical Natural Resources, \\ Kasetsart University, Bangkok 10900, Thailand \\ fforsws@ku.ac.th
}

ABSTRACT. Paraboea khaoyaica Kaitongsuk, Triboun \& Sungkaew, a new species from Southeastern Thailand, is described and illustrated and its conservation status is assessed. The species is currently only known from the type locality.

Keywords. Asia, endangered, Khao Yai National Park

\section{Introduction}

The genus Paraboea (C.B.Clarke) Ridl., distributed in tropical Asia with about 130 species (Triboun \& Middleton, 2015), is one of the largest genera in the Gesneriaceae (Weber, 2004; Puglisi \& Phutthai, 2017). The genus was revised by Xu et al. (2008), since when the two genera Trisepalum C.B.Clarke and Phylloboea Benth. have been synonymised into Paraboea based on evidence from a molecular phylogenetic study by Puglisi et al. (2011). Ongoing work to revise the genus for the Flora of Thailand has already led to the description of more than twenty new species from Thailand (Triboun \& Middleton, 2012, 2015; Triboun, 2013; Puglisi \& Phutthai, 2017). During a botanical expedition to Khao Yai National Park led by the first author in September 2019, an unknown Paraboea species was collected and examined. It does not match any of the previously known species of the genus. Therefore, it is here described and illustrated for the first time. Other useful information is also provided. 


\section{New species}

Paraboea khaoyaica Kaitongsuk, Triboun \& Sungkaew, sp. nov.

Paraboea khaoyaica is similar to Paraboea pubicorolla Z.R.Xu \& B.L.Burtt in having 1-3 subterminal inflorescences, leaves that are elliptic or ovate and with narrow wings at the base of the petiole joining across the nodes, and, unusually for species in the genus, occurs in a similar sandstone habitat. It differs in having a glabrous and flatfaced campanulate corolla with tube 4-5 mm long (vs a glandular hairy and deeply campanulate corolla with tube c. $7 \mathrm{~mm}$ long in Paraboea pubicorolla), filaments 1.5-2 mm long and glabrous (vs c. $4 \mathrm{~mm}$ long and pubescent in P. pubicorolla), and capsules 1-1.5 cm long (vs 2.5-3 cm long in P. pubicorolla). Paraboea khaoyaica is also similar to $P$. chumphonensis Triboun in the similar size of leaves and its flatfaced campanulate corolla with tube c. $4 \mathrm{~mm}$ long. It differs, however, in having a glabrous ovary (vs pubescent ovary in Paraboea chumphonensis), slightly shorter and glabrous capsules $1-1.5 \mathrm{~cm}$ long (vs slightly longer capsules c. $1.8 \mathrm{~cm}$ long which are covered with glandular hairs in $P$. chumphonensis), and occurrence in a sandstone habitat (vs limestone habitat in P. chumphonensis). - TYPE: Thailand, Prachin Buri, Prachantakham, Khao Yai National Park, 14¹1'11.1"N 101²9'51.5"E, 3 September 2019, Kaitongsuk, Triboun, Uearee, Nitmee, Sreesaeng \& Kaewsri S.K. 336/1 (holotype $\mathrm{BKF}$; isotype BK). (Fig. 1 \& 2).

Lithophytic perennial herb. Stem erect, 8-25 $\mathrm{cm}$ high, slender, 4-10 $\mathrm{mm}$ in diameter, semi-woody, cracked and longitudinally wrinkled, all parts covered with dense white hairs; rootstock cracked and corky with parallel grooves. Leaves 7-16, densely decussate, crowded towards the apex of stem; petiole up to $5 \mathrm{~cm}$ long, 2-3 $\mathrm{mm}$ in diameter, with narrow wings at base, joining across the nodes, densely covered with white hairs; blade chartaceous, elliptic or ovate, $6.5-15 \times 2.5-5.5 \mathrm{~cm}$, apex obtuse, base decurrent cuneate or attenuate, margin slightly crenate, densely covered with indumentum on both sides, secondary veins 4-8 on each side of midrib, sunken above and prominent below, tertiary veins reticulate. Inflorescences 1-3, subterminal, compound monochasia, with 1-3 orders of branching, congested; peduncle green to purplish red, 9-15.5 cm long, 0.5-1 $\mathrm{mm}$ in diameter with white hairs at base; bracts linear or lanceolate, 4-5 × 1.5-2 mm, the upper ones strongly reduced, $2.5-3 \times 1-1.5$ $\mathrm{mm}$; flowers paired; pedicels 2-4 $\mathrm{mm}$ long. Flower bud light mauve, 3-4 $\mathrm{mm}$ in diameter Calyx green to purplish red, fused at base, c. $1 \mathrm{~mm} \mathrm{long,} \mathrm{divided} \mathrm{into} 5$ lobes; lobes narrowly triangular, 3-3.5 $\times 0.5-1 \mathrm{~mm}$, apex acute, glabrous. Corolla glabrous, white to very light mauve, rotate to shallowly campanulate, 5-lobed; tube 4-5 mm long; lobes orbicular or broadly ovate, 4-5 $\times 5-6 \mathrm{~mm}$, apex rounded. Stamens 2, inserted near base of corolla tube; filaments orange, geniculate, 1.5-2 mm long, c. $0.5 \mathrm{~mm}$ wide, glabrous; anthers light yellow, c. $3 \times 2 \mathrm{~mm}$; staminodes 3 , attached near base of corolla tube. Ovary cream-white, ovoid, c. $2 \mathrm{~mm}$ long, glabrous; style light mauve, 3-4 mm long; stigma capitate, white or light mauve. Capsules plagiocarpic, narrowly cylindric, $1-1.5 \times 0.1-0.2 \mathrm{~cm}$, slightly twisted, glabrous; calyx persistent, pale green when young, brown when mature. 


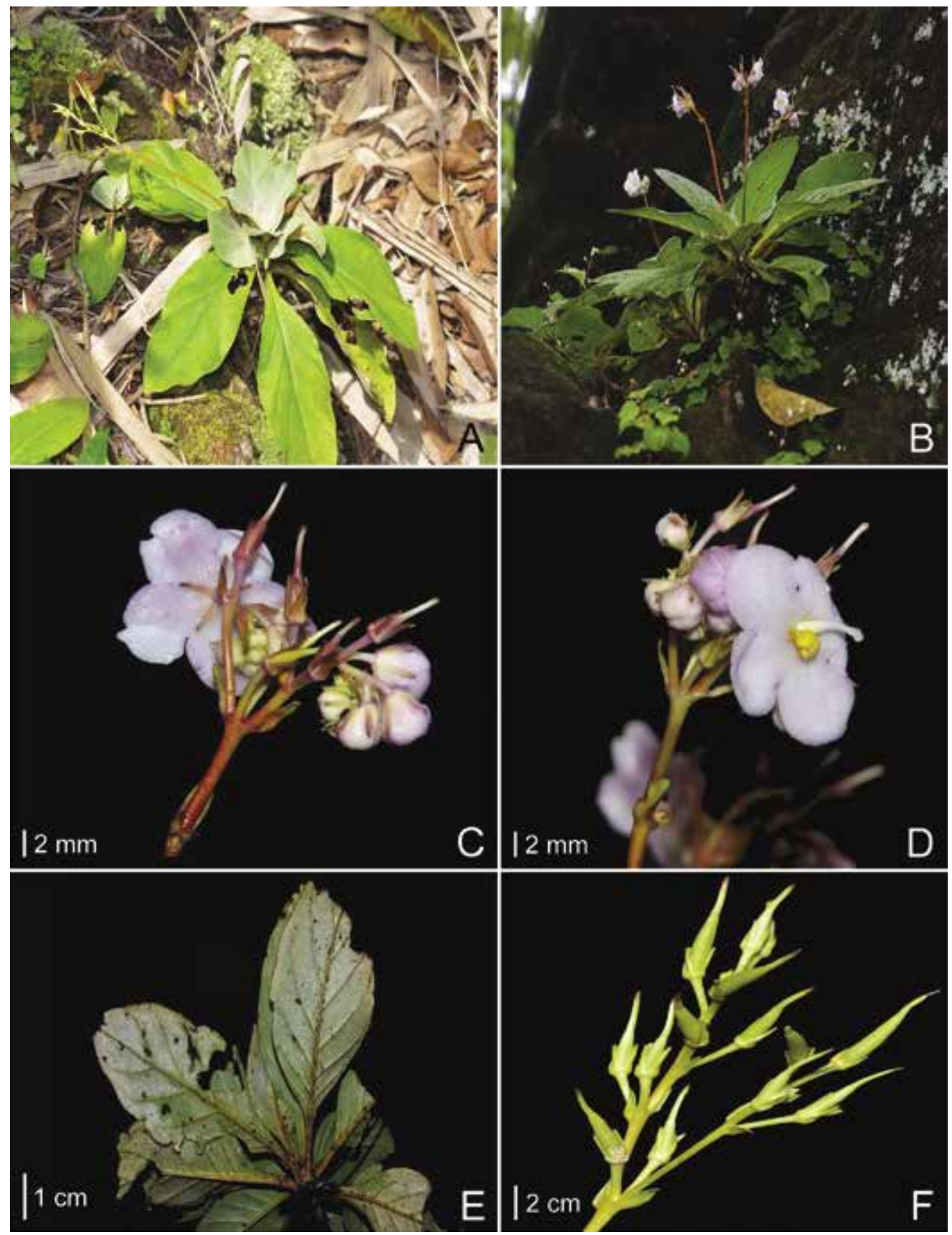

Fig. 1. Paraboea khaoyaica Kaitongsuk, Triboun \& Sungkaew. A-B. Habit. C. Inflorescence with open flowers (back view), flower buds and young fruits. D. Inflorescence with open flower (front view), flower buds and young fruits. E. Undersurface of leaves. F. Infructescence with young fruits. (Photos: S. Kaitongsuk). 
206

Gard. Bull. Singapore 73(1) 2021

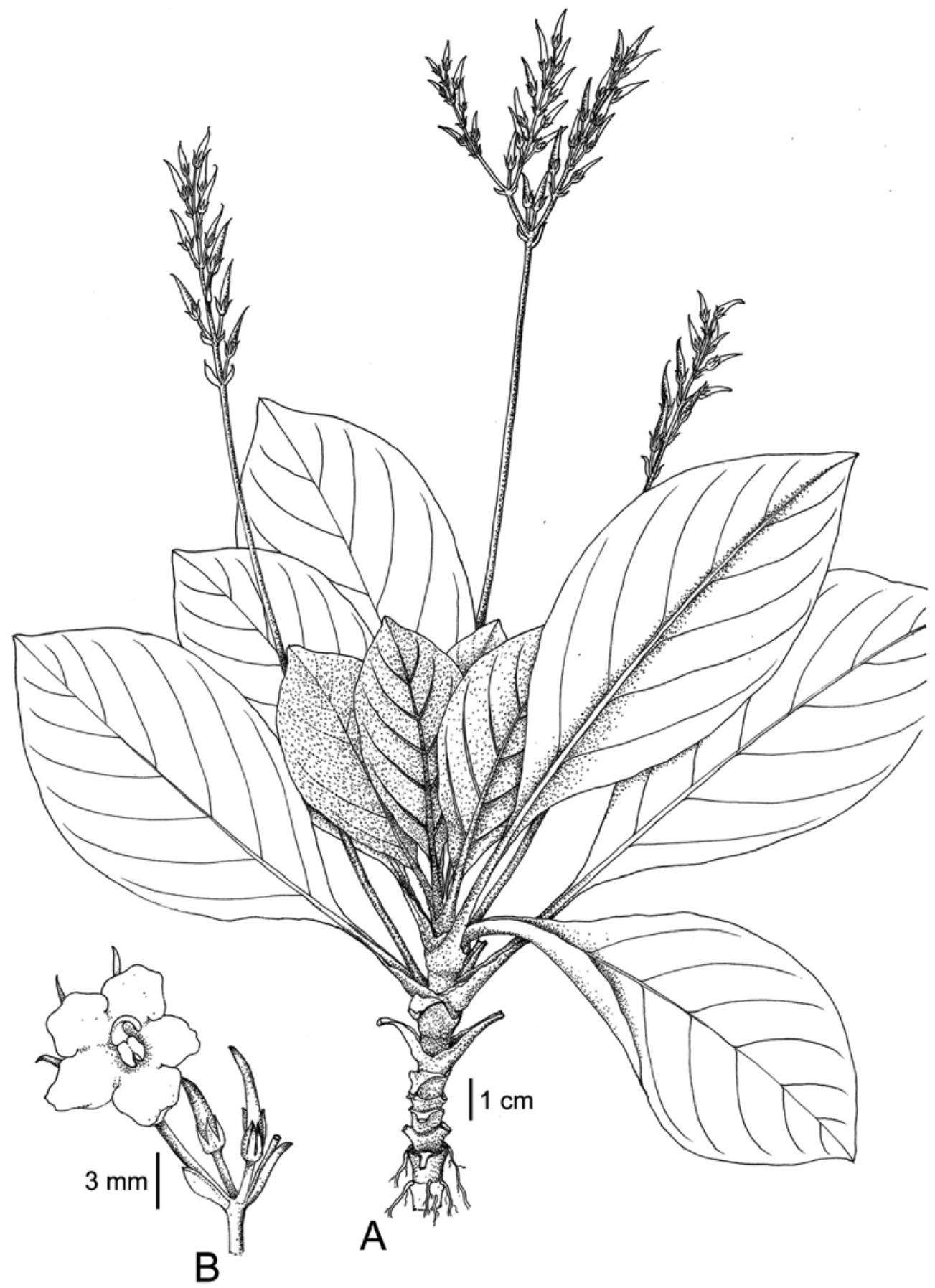

Fig. 2. Paraboea khaoyaica. A. Habit. B. Open flower and young fruits. Drawn by Orathai Kerdkaew. 
Distribution. Endemic to Southeastern Thailand.

Ecology. Growing on sandstone rocks along a stream and on moist rocks in partial shade in bamboo and dry dipterocarp forest, alt. 100-150 m.

Phenology. Flowering and fruiting between August and November.

Etymology. The specific epithet refers to Khao Yai National Park (the type locality).

Vernacular name. Cha Rue Si Khao Yai (ชาฤาษีเขาใหญ่).

Provisional IUCN conservation assessment. Following the IUCN Red List categories and criteria (IUCN Standards and Petitions Committee, 2019), Paraboea khaoyaica is assessed as Endangered (EN B1ab(iii) + B2ab(iii)). It is only known from three locations from sandstone vegetation in bamboo and dry dipterocarp forest in Khao Yai National Park with an Extent of Occurrence (EOO) of around $20 \mathrm{~km}^{2}$, and an estimated known Area of Occupancy (AOO) of around $8 \mathrm{~km}^{2}$. The principal threat is that the area is seasonally dry between March and April and prone to fire.

ACKNOWLEDGEMENTS. We thank Mr Yannawut Saengwong, Mr Pongsak Kaewsri, Mr Jakkrit Sreesaeng, Mr Pongsakorn Nitmee and the ranger officers of Khao Yai National Park for their assistance during the fieldwork. We thank Ms Orathai Kerdkaew for providing the line drawing.

\section{References}

IUCN Standards and Petitions Committee (2019). Guidelines for Using the IUCN Red List Categories and Criteria. Version 14. Prepared by the Standards and Petitions Committee. Available from http://www.iucnredlist.org/documents/RedListGuidelines.pdf.

Puglisi, C., Middleton, D.J., Triboun, P. \& Möller, M. (2011). New insights into the relationships between Paraboea, Trisepalum, and Phylloboea (Gesneriaceae) and their taxonomic consequences. Taxon 60(6): 1693-1702.

Puglisi, C. \& Phutthai, T. (2017). A new species of Paraboea (Gesneriaceae) from Thailand. Edinburgh J. Bot. 75(1): 51-54.

Triboun, P. (2013). Paraboea middletonii (Gesneriaceae), a new species from Thailand. Thai Forest Bull., Bot. 41: 45-47.

Triboun, P. \& Middleton, D.J. (2012). Twenty new species of Paraboea (Gesneriaceae) from Thailand. Gard. Bull. Singapore 64: 333-370.

Triboun, P. \& Middleton, D.J. (2015). Three new species of Paraboea (Gesneriaceae) from Thailand. Thai Forest Bull., Bot. 43: 18-23.

Weber, A. (2004). Gesneriaceae. In: Kubitzki, K. \& Kadereit, J.W. (eds) The Families and Genera of Vascular Plants, vol. 7. Berlin/Heidelberg: Springer.

Xu, Z., Burtt, B.L., Skog, L.E. \& Middleton, D.J. (2008). A revision of Paraboea (Gesneriaceae). Edinburgh J. Bot. 65: 161-347. 
